\title{
Research on Ownership Structure and Stock Price Fluctuation
}

\author{
Weice $\mathrm{Ni}$ \\ Business School of Sichuan University, Chengdu, Sichuan Province, China \\ 2414562379@qq.com
}

Keywords: Ownership concentration; Ownership balance; State holdings; Stock volatility; Public utility

\begin{abstract}
Based on the sample of A-share listed companies in 2015, we take an empirical research of the stock volatility of Listed Public Utility units from the perspective of ownership structure. The empirical results show that the institutional shareholders of listed companies in public utilities in China have the motive to promote the volatility of the stock price, while the state-owned shareholders play a role in stabilizing stock price volatility. In order to reduce the ability of the institutional shareholders to manipulate the stock price, we suggest that the government should increase the intensity of investment in public utilities. And in order to prevent the institutional shareholders promote the stock price vibration wantonly, the government should speed up the establishment of the delisting mechanism.
\end{abstract}

\section{Introduction}

In September 6, 2013, The State Council issued About strengthening the construction of urban infrastructure, requiring governments at all levels to focus on key areas to Improve the level of urban infrastructure construction in every aspect. The Four-Pronged Comprehensive Strategy also stressed that "Make sure to build a comprehensive society in 2020". Therefore, it has a very important practical significance to ensure the stability of listed public utility companies, to make it fully into the promotion of urban and rural infrastructure construction to improve people's living standards at present.

Ownership structure is the basis of corporate governance structure. Ownership structure has being studied by a lot of scholars this year. Does the enterprise has enough potential to go forward, or has bankruptcy risk? We can find the answer from its corporate governance mode. The ownership structure of enterprise in each country is not exactly the same. Yanhong Li (2008) [1] divided the foreign enterprise ownership structure into two categories: external monitoring and internal control, and consider that the composition of a country's mainstream enterprise equity structure is related to its national history. There is no definite conclusion on whether the optimal ownership structure exists in academia. In this paper, we chooses the listed public utility enterprises in 2015 as the research sample, use the Stock price variance of Listed public utility units divided by the stock price mean of Listed public utility units to estimate stock volatility, and select the ownership concentration, equity balance and the proportion of government shares to measure the ownership structure of listed public utilities. We also add the price cash flow ratio, asset size and total Rate of Return on Total Assets into our model. Finally, we use this model to study the impact of ownership structure on stock volatility.

\section{Literature Review}

At present, domestic scholars and foreign scholars have some achievement on the influencing factors of stock price volatility, Zhang et al (2011)[2] divide investors into fundamentalists and chartists, make a study on the impact of investor risk attitude on stock price fluctuation; Aydemir and Abdullah Cevdet (2005)[3] studied the impact of market risk on stock price volatility. Wen et al (2010) [4] said the stock price volatility will affect the health of investors----leading to an increase in the incidence of coronary heart disease. X Song and W Zheng (2014) [5] is taking into account the impact of analyst independence on stock price volatility. Yuanyuan Chen [6] takes a research on 
stock volatility based on life cycle theory. In summary, the research on the influencing factors of stock price volatility is mainly based on the statistical analysis of volatility curve and the influence of macroeconomic cycle and economic situation.

There is a lot of research on the ownership structure, too. S Stepanov and A Suvorov (2015) [7]studied the relationship between ownership structure and agency issues; Q He and O M Rui (2016)[8]studied the impact of ownership structure on internal transactions; Haw et al (2010)[9] said that the high concentration of equity will make the performance of commercial banks worse, and make operating performance instability; La Porta (2002) [10]put forward the "two-handed theory", he argue that government holdings have two effects: On the one hand, the "two-handed theory" said that the government has the motivation to influence the normal operation of the enterprise through political ties, in order to achieve government performance. These actions always tend to harm the interests of banks, La Porta call it "plunder of the hand". On the other hand, government background enterprises are also easy to get government support, such as get more and lower interest rates of loans from the bank, or access to tax incentives, to ensure that enterprises more stable operation.

\section{Research Design}

Different from other securities market of the developed countries, China's securities market started late. There are only seven companies listed transactions when Shanghai Stock Exchange was established in 1900. Therefore, compared with the foreign relatively mature capital market, China's securities market is not perfect, laws and regulations need to be improved. In this case, many listed companies to carry out illegal operations to obtain excess profits. These phenomena increase the systemic risk of China's securities market. On the other hand, investors account for the majority of small and medium shareholders. These investors do not have a strong sense of investment, and always lack of necessary securities theory knowledge. They often have gambling psychology, pursuit of short-term interests, resulting in a series of irrational behavior. This is also a strong reason for China's capital market vibration. China's securities market does not have a reasonable delisting mechanism; listed companies will not really feel the pressure to withdraw from the market. It makes the major shareholders of China's listed companies will not take the initiative to control the abnormal fluctuations in stock prices, but will use the internal message more convenient access to stock price spread, infringement of the legitimate rights and interests of small investors. The restrictions on the rights of large shareholders really reduce the majority of shareholders through internal information to obtain illegal profit behavior, but there is a much more bigger problem: because there are more shareholders share the Company control, they have a requirement to allocate certain benefits, the major shareholders in order to obtain sufficient benefits to allocate, will intensify Stock prices volatility, to get a greater interest space for more control of the shareholders to allocate. Due to the long-term holdings of the country, in those enterprises which most of the shares under state control, making the hands of other shareholders in the relatively small chips, it is difficult to trigger the volatility of corporate stock prices by institutional shareholders. So, the stability of the state holdings is conducive to the stability of the stock price. Therefore, we make the following Hypothesis:

Hypothesis 1: The concentration of equity of listed companies in China is positively related to stock price volatility.

Hypothesis 2: The equity balance of listed companies in China is positively related to stock price volatility.

Hypothesis 3: The state ownership ratio of listed companies and stock price volatility are negatively correlated.

Engle(1982) [11]Proposed to use Auto-regressive Conditional Heteroskedasticity to measure stock volatility, Clarke and Parrott (1999)[12] proposed the Stochastic Volatility model to measure stock volatility, This is the two most common stock price volatility measurement model. In addition, some scholars through the self-built model to measure the volatility of stock prices. Taking the 
problem of data acquisition into account, we chooses the Stock price variance of Listed public utility units divided by the stock price mean of Listed public utility units to estimate stock volatility, fully consider the difference between the listed company's stock price and the variance. According to the meaning of the two-tier structure of equity, we use ownership concentration, ownership balance and state ownership ratio as control variable. And the ownership concentration is measured by the sum of the top five shareholders of listed companies, the ownership balance is measured by the ratio of the shareholding ratio of the second to the fifth largest shareholder to the proportion of the largest shareholder, the state ownership ratio is measured by the sum of the shareholdings of all levels of government. Finally, we fully takes the impact of individual risk, asset size and operating performance on the stock price of listed companies into account, adding the price cash flow ratio, asset size and total Rate of Return on Total Assets respectively as control variables. The price cash flow ratio is measured by the ratio of the net cash flow of the index constituent stocks to the total market value of the constituent stocks, the asset size is measured by the total assets of the listed company, and the total Rate of Return on Total Assets is measured by the ratio of net profit to total assets of listed company. The variables defined in this paper are shown in Table 1:

Table 1 Definition of model variables and measurement methods

\begin{tabular}{|l|l|l|l|}
\hline $\begin{array}{l}\text { Variable } \\
\text { type }\end{array}$ & Variable name & $\begin{array}{l}\text { Variable } \\
\text { symbol }\end{array}$ & Variable measure method \\
\hline $\begin{array}{l}\text { Dependent } \\
\text { variable }\end{array}$ & Stock volatility & VOL & Stock price variance / stock price mean \\
\hline \multirow{4}{*}{$\begin{array}{l}\text { Explanatory } \\
\text { variables }\end{array}$} & $\begin{array}{l}\text { Ownership } \\
\text { concentration }\end{array}$ & $\mathrm{S}_{5}$ & $\begin{array}{l}\text { The sum of the proportion of the top five } \\
\text { shareholders }\end{array}$ \\
\cline { 2 - 4 } & $\begin{array}{l}\text { Oalance } \\
\text { state ownership } \\
\text { ratio }\end{array}$ & Z & $\begin{array}{l}\text { The second to the five largest shareholder of the } \\
\text { proportion of shares/ The proportion of the largest } \\
\text { shareholder }\end{array}$ \\
\hline \multirow{2}{*}{$\begin{array}{l}\text { Control } \\
\text { variable }\end{array}$} & $\begin{array}{l}\text { The price cash } \\
\text { flow ratio }\end{array}$ & PCF & $\begin{array}{l}\text { Net cash flow for for the constituent stocks / The total } \\
\text { market value of the constituent stocks }\end{array}$ \\
\cline { 2 - 5 } & asset size & SIZE & The total assets take the logarithm \\
\cline { 2 - 5 } & $\begin{array}{l}\text { total Rate of } \\
\text { Return }\end{array}$ & ROA & Net profit / Total assets \\
\hline
\end{tabular}

Finally, we get the following regression model:

$$
\text { VOL }=\alpha+\beta_{1} S_{5}+\beta_{2} Z+\beta_{3} \text { SOSP }+\beta_{4} \text { PCF }+\beta_{5} \text { SIZE }+\beta_{6} \text { ROA }+\varepsilon
$$

Where $\alpha$ is a constant term, $\beta_{\mathrm{i}}$ is the regression coefficient, and $\varepsilon$ is the error term.

\section{Empirical Analysis}

We choose the Public utility companies listed in the A-share in 2015. After removing the ST plate, there are 379 valid sample companies were obtained as our research samples. The data selected in this article are derived from the CSMAR database. The correlation analysis of the model variables involved in this paper is shown in Table 2: 
Table 2 Main variable relevance

\begin{tabular}{llllllll}
\hline $\begin{array}{l}\text { Pearson correlation } \\
\text { coefficient }\end{array}$ & VOL & $\mathrm{S}_{5}$ & $\mathrm{Z}$ & SOSP & PCF & SIZE & ROA \\
\hline VOL & 1 & & & & & & \\
$\mathrm{~S}_{5}$ & $0.104^{* *}$ & 1 & & & & & \\
$\mathrm{Z}$ & $0.163^{* * * *}$ & $-0.042^{* * * *}$ & 1 & & & & \\
SOSP & $-0.110^{* *}$ & $0.176^{* * *}$ & $-0.086^{*}$ & 1 & & & \\
PCF & $0.123^{* *}$ & $0.059^{* * *}$ & $-0.0199^{* * *}$ & 0.012 & 1 & & \\
SIZE & $-0.307^{* * *}$ & $0.216^{* * *}$ & $-0.108^{* *}$ & $0.092^{*}$ & $0.160^{* *}$ & 1 & \\
ROA & $0.112^{* *}$ & $0.192^{* * *}$ & 0.077 & 0.040 & -0.006 & 0.023 & 1 \\
\hline
\end{tabular}

Note: $* * *, * *, *$ were significantly correlated at 0.01 level (bilateral), 0.05 level (bilateral) and 0.1 level (bilateral), respectively.

Person correlation analysis shows that there is no multicollinearity between the variables, so we can carry out regression analysis. The regression analysis results are shown in Table 3:

Table 3 Regression results

\begin{tabular}{l|l|l|l|l}
\hline \multirow{2}{*}{ variable name } & \multirow{2}{*}{ coefficient } & \multirow{2}{*}{$\mathrm{P}$} & \multicolumn{3}{|l}{ Collinearity Statistics } \\
\cline { 4 - 5 } & & & Tolerance & VIF \\
\hline Constant & $45.591^{* * *}$ & 0.000 & & \\
\hline $\mathrm{S}_{5}$ & $0.091^{* * *}$ & 0.000 & 0.895 & 1.118 \\
\hline $\mathrm{Z}$ & $1.082^{* *}$ & 0.011 & 0.975 & 1.026 \\
\hline SOSP & $-6.143^{* *}$ & 0.038 & 0.959 & 1.043 \\
\hline PCF & $0.002^{* * *}$ & 0.00 & 0.973 & 1.027 \\
\hline SIZE & $-2.239^{* * *}$ & 0.00 & 0.919 & 1.088 \\
\hline ROA & $11.761^{*}$ & 0.086 & 0.956 & 1.047 \\
\hline Non & & &
\end{tabular}

Note: $* * *, * *, *$ were significantly correlated at 0.01 level (bilateral), 0.05 level (bilateral) and 0.1 level (bilateral), respectively.

The regression results in Table 3 show that: The regression coefficient of ownership concentration is 0.091 , and it is significant at 0.01 level, indicating that the greater the rights of large shareholders, the more likely to use the right to promote the stock price volatility, in order to get stock price spreads, this conclusion supports the first hypothesis of this paper; The regression coefficient of the ownership balance variable is 1.082, and it is significant at the 0.05 level, indicating that the restraint of other shareholders to the rights of major shareholders did not reduce the volatility of the stock price of listed companies, on the contrary, making stock prices more volatile, because of more shareholders mean that more stock price space is needed to gain revenue to meet the interests of more shareholders, this conclusion supports the second hypothesis of this paper; The regression coefficient of the proportion of state shareholders is -6.143 and is significant at 0.05 level, indicating that the existence of state shareholders, can inhibit the level of stock price fluctuations in listed companies. This conclusion supports the third hypothesis of this paper.

\section{Conclusions}

We selected public utility A-share listed companies in 2015 as samples, and discuss the volatility of stock price from the perspective of ownership structure. The final empirical results show that, in Public utilities listed companies, Controlling shareholders always use information asymmetry advantage obtain high returns, by manipulating stock price volatility. This behavior exists not only 
in the major shareholders, but also in other shareholders who can benefit from stock price volatility. And when the number of shareholders who can benefit from stock price volatility increases, they will drive more volatility in order to get enough benefits for them to allocate. The root cause of this problem is that listed companies do not have to worry about delisting, so that shareholders of listed companies can be impulsive to promote the stock price shocks.

Under the call of "building a moderately prosperous society", to maintain the stability of public utility unit stock prices, will let managers put more energy in improving infrastructure. Therefore, we make the following recommendations: First, public utilities listed companies should establish a reasonable ownership structure, this means that there should be a legitimate powerful institutional shareholder to appear and raise the proportion of state ownership. Secondly, we recommend that a reasonable supervisory mechanism should be established to promote the perfection of the delisting mechanism. The government should speed up the establishment of the delisting mechanism to prevent the institutional shareholders promote the stock price vibration wantonly and establish a good market order.

\section{References}

[1] Li Yanhong. Onwership Structure and Commercial Bank Performance: International Comparison and China's Empirical Study [J]. Financial Research, 2008 (11): 138-145. (In Chinese)

[2] Y Zhang and H Li. Investors' risk attitudes and stock price fluctuation asymmetry [J]. Physica A: Statistical Mechanics and its Applications, 2011, 390(9): 1655-1661.

[3] Aydemir and Abdullah Cevdet: Stock volatility and correlations in dynamic general equilibrium models(Ph.D., Carnegie Mellon University, American 2005),p.1

[4] W Ma, H Chen and L Jiang, et al. Stock volatility as a risk factor for coronary heart disease death [J]. European heart journal, 2010: ehq495.

[5] X Song and W Zheng. Ownership structure, stock volatility and analyst independence: evidence from China [J]. China Finance Review International, 2014, 4(2): 187-208.

[6] Chen Yuanyuan. Economic Cycle Theory and Industry Stock Price Fluctuation [J]. Enterprise Reform and Management, 2015 (8): 101-101. (In Chinese)

[7] S Stepanov and A Suvorov. Agency problem and ownership structure: Outside blockholder as a signal [J]. 2015.

[8] Q He and O M Rui. Ownership structure and insider trading: evidence from China [J]. Journal of Business Ethics, 2016, 134(4): 553-574.

[9] I M Haw, S S M Ho and B Hu, et al. Concentrated control, institutions, and banking sector: An international study [J]. Journal of Banking \& Finance, 2010, 34(3): 485-497.

[10]La Porta R, Lopez-de-Silanes F and A Shleifer. Government ownership of banks [J]. The Journal of Finance, 2002, 57(1): 265-301.

[11]R F Engle. Autoregressive conditional heteroscedasticity with estimates of the variance of United Kingdom inflation [J]. Econometrica: Journal of the Econometric Society, 1982: 987-1007.

[12]N Clarke and K Parrott. Multigrid for American option pricing with stochastic volatility [J]. Applied Mathematical Finance, 1999, 6(3): 177-195. 